\title{
EFFECTS OF LEAD WATER IRRIGATION UNDER ZEOLITE STRESS ON RICE GROWTH
}

\author{
ZHANG, L. - BAI, Y. K. ${ }^{*}$ - LI, Y. Q. - JIANG, G. H. \\ Shenyang Agricultural University, No. 120 Dongling Road, Shenyang, Liaoning, China \\ (phone: +86-24-8848-7134; fax: +86-24-8848-7134) \\ *Corresponding author \\ e-mail: baiyikui@163.com; phone: +86-133-8683-4288
}

(Received 28 $8^{\text {th }}$ Apr 2019; accepted 12 $2^{\text {th }}$ Jul 2019)

\begin{abstract}
This paper aims to study the effects of lead concentration in irrigation water on the yield and growth traits of rice under soil zeolite stress, with the addition of lead accumulation in rice plants, which were tested in a micro zone at the Experimental Base of Water Conservancy in Shenyang Agricultural University of Liaoning Province, China, through the application of different amounts of zeolite $\left(0,2500,5000 \mathrm{~kg} \cdot \mathrm{ha}^{-1}\right)$ and different lead concentrations $\left(0,0.25,0.2,0.15 \mathrm{mg} \cdot \mathrm{L}^{-1}\right)$ in irrigation water. It was concluded that the lead contents in paddy root, stem, leaf and rice significantly varied with different exogenous lead concentrations. With the increase of the concentration, the lead contents in each part were significantly increased. More importantly, the effect on aboveground material weight was greater than that on underground material weight. The water contents of rice were increased with the decrease in the protein content, and starch content was decreased under zeolite stress. When the concentration of lead increased, the effect was more pronounced. Comprehensive test with various factors indicated that the incorporation of zeolite in soil for rice cultivation with lead-contaminated water irrigation or lead contaminated soil could restrain the movement of lead ions into the rice.
\end{abstract}

Keywords: zeolite, lead, quality of rice, enrichment ability, interaction

\section{Introduction}

In recent years, the use of one of China's shortage resources-agricultural irrigation water-has seen an increasing trend concerning industries and urban environments due to the acceleration of industrialization and urbanization, and the rapid development of technology, economy, civilization and people's quality of life. Therefore, the condition of agricultural water is getting worse. To make matters worse, irrigation with contaminated water is becoming one of the major methods to deal with the deficiency of water. In such cases, researches about the effects of recycling water irrigation on the yield and quality of agricultural products attract more attention recently (Galvis et al., 2018; Becerra, 2015). Lead is one of the most toxic elements among all known metal contaminations causing fertility deterioration, reproductive organ tumors, decreased immunity as well as physical anomalies (Zhao et al., 2015) of various organisms including humans. The increased lead level in children's body would damage the brain and nervous system, destroying cerebral cortical cells, which results in mental decline and impaired attention (Zhang et al., 2014). The $\mathrm{Pb}^{2+}$ in contaminated water will enter soil, get absorbed by root system and accumulate in plants. Once the concentration of $\mathrm{Pb}^{2+}$ exceeds a certain level, plants will be poisoned, and eventually $\mathrm{Pb}^{2+}$ will enter human bodies through the food chain to damage our health (Chen et al., 2018; Abrahams, 2002; Luo, 2012). It was revealed that lead would accumulate in rice plants to inhibit their growth, and to degrade their yield and quality (Ashraf et al., 2015; Chen et al., 2010). In China, paddy rice is one of the staple food crops for food supply (Khush, 2013; Huang, 2011). Therefore, it is of key 
importance to study how to reduce the absorption and accumulation of lead in paddy rice.

In recent years, many scholars have been focusing on heavy metal contaminated soil treatment with soil conditioner, such as commonly used lime, phosphate, compost, blast furnace slag, molysite, silicate, and zeolite (Gray, 2006; Theodoratos, 2002; Qian, 2009). As a common adsorbent, zeolite can not only improve soil condition, but also purify waste water by removing of heavy metal (Merrikhpour et al., 2013; Shi et al., 2009). Zeolite has porous aluminosilicate mineral, its unique three-dimensional space frame structure makes it have a huge specific surface area, ion has a great adsorption capacity and adsorption exchange capacity, is considered as an economic and efficient heavy metal pollution remediation material, the lead in wastewater has adsorption effect. In addition, some scholars believe that the passivation of zeolite is due to the strong adsorption of heavy metal through its silicon oxygen and aluminum oxygen tetrahedron structure. Zeolite has a certain passivation effect on heavy metal lead in soil, which can effectively inhibit the migration and ecological effectiveness of soil lead (Zhou et al., 2014a). Natural zeolite, as an inorganic soil conditioner, has been widely used to improve the growth and yield of upland crops due to its high cation exchange capacity and intensive affinity for nutrients and water (Malekian et al., 2011; Aghaalikhani et al., 2012; Hazrati, 2017). On top of that, zeolite can also passivate lead in soil to inhibit lead migration and ecological availability in soil (Altaf et al., 2019). Several studies have been conducted for joint use of various soil conditioners (Zhou et al., 2014b, 2017; Wu al., 2016; Yang et al., 2016) for lead-contaminated soil. However, most of these studies are performed in pot experiments with only a few in regional experiments. At the same time, most studies focused on the influence of composite conditioners on soil contamination or improvement of wastewater through zeolite, while researches on rice yield, lead concentration and growth traits of paddy plant affected by zeolite and leadcontaining water were rare. Therefore, this paper aims to analyze effects of exogenous lead on the yield of rice under soil zeolite stress, lead accumulation in rice plant, and growth traits through paddy rice planting in small regions to provide a reference for finding ways to reduce lead contamination in paddy rice.

\section{Materials and methods}

\section{Material for experiment}

This study used a local, mid-late season rice (Oryza sativa L.) cultivar, Shennong 9816, bred by the Rice Research Institute of Shenyang Agricultural University and characterized by high yield, good quality, and strong disease resistance, with brown earth soil for the base. All physicochemical indices are as follows: $\mathrm{pH}$ value 7.41; organic substance contents $20.48 \mathrm{~g} \cdot \mathrm{kg}^{-1}$; total nitrogen contents $1.3 \mathrm{~g} \cdot \mathrm{kg}^{-1}$, rapidly available phosphorus $20.69 \mathrm{mg} \cdot \mathrm{kg}^{-1}$; rapidly available potassium $50.11 \mathrm{mg} \cdot \mathrm{kg}^{-1}$. Applied regular fertilizers are as follows: potassium sulfate $100 \mathrm{~kg} \cdot \mathrm{ha}^{-1}$; carbamide $300 \mathrm{~kg} \cdot \mathrm{ha}^{-1}$; monocalcium phosphate $200 \mathrm{~kg} \cdot \mathrm{ha}^{-1}$. The irrigation water is from the comprehensive experiment base of College of Water Resource. As verified through inspection, the irrigation water met potable water standards, with lead concentrations $<0.06 \mu \mathrm{g} \cdot \mathrm{L}^{-1}$.

\section{Methods}


The experiment was carried out in non-weighing lysimeters at the College of Water Resource of Shenyang Agricultural University of Liaoning Province, China ( $42^{\circ} 08^{\prime} 57^{\prime \prime} \mathrm{N}$, $120^{\circ} 30^{\prime} 45^{\prime \prime} \mathrm{E}, 47 \mathrm{~m}$ altitude), during one rice-growing seasons (May to October in 2018). The study area has a temperate continental monsoon climate with $7.5{ }^{\circ} \mathrm{C}$ average annual air temperature. Average annual rainfall is $672.9 \mathrm{~mm}$, with the main rainy season from June to September. The regional area for experiment $(3.5 \mathrm{~m}$ long $\times 1.2 \mathrm{~m}$ wide $\times 0.3 \mathrm{~m}$ deep) were constructed from concrete blocks and sealed with waterproof paint to prevent seepage between plots. In order to prevent irrigation water in the micro zone from being diluted by rain and thus affecting the test results, transparent awnings were set up, covered by rainy days, and all opened on sunny days, and the planting rate between rice plants was $20 \times 25 \mathrm{~cm}$. The experiment has two factors (lead and zeolite) with four levels of lead concentration and three zeolite application rates. There were nine treatment methods as shown in Table 1. Each treatment was repeated 3 times. Zeolite was applied all at once during soil harrowing before fertilization and transplantation of paddy plant. During the growth delaying period, all of the nine treatment the areas were irrigated with water from the experiment base, and since seedling establishment period, the areas were irrigated with water of different lead concentrations. The CK area was irrigated with clean water.

Table 1. Factors and levels of the experiment

\begin{tabular}{c|c|c|c|c|c}
\hline Treatment & CK & I & III & IV & V \\
\hline $\mathrm{W}_{0} / \mathrm{kg} \cdot \mathrm{ha}^{-1}$ & 0 & 2500 & 2500 & 2500 & 2500 \\
$\mathrm{~Pb} / \mathrm{mg} \cdot \mathrm{L}^{-1}$ & 0 & 0 & 0.15 & 0.2 & 0.25 \\
\hline Treatment & CK & II & VI & VII & VIII \\
\hline $\mathrm{W}_{0} / \mathrm{kg} \cdot \mathrm{ha}^{-1}$ & 0 & 5000 & 5000 & 5000 & 5000 \\
$\mathrm{~Pb} / \mathrm{mg} \cdot \mathrm{L}^{-1}$ & 0 & 0 & 0.15 & 0.2 & 0.25 \\
\hline
\end{tabular}

The sampling procedure consisted of randomly taking 5 plants for each treatment during the maturity period of the paddy rice. A soil auger was used to obtain $0.5-1 \mathrm{~kg}$ of soil at a depth of $0-20 \mathrm{~cm}$. The roots were carefully rinsed from the soil with a hydropneumatic device and detached from their nodal bases. For the growth traits measurements, the height of the sample plants, the tiller number and the biomass of the substances above ground and below ground were all taken. The samples were then treated as follows. The soil samples were dried naturally in the shade, ground and screened with a 100 mesh screen. The plants were oven-dried, crushed with a plant pulverizer, ground into powder via a mortar, and screened with a 100 mesh screen.

Using a GB5009.12-2017 A pressure dissolution vessel was used to treat samples via the digestion method, and an atomic absorption spectrophotometer (HITACHI Z-2000) (Fig. 1) was used to determine the lead content via the flame method. The FOSS (Fig. 2) was utilized to determine rice qualities, such as water content, protein, and amylase.

\section{Data processing}

The analysis software SPSS19.0 was used for one-way ANOVA. Notable comparison of data was made by using Duncan inspecting method $(\mathrm{P}<0.05)$. Software Design-Expert 8.0 was used to calculate the optimum point. 


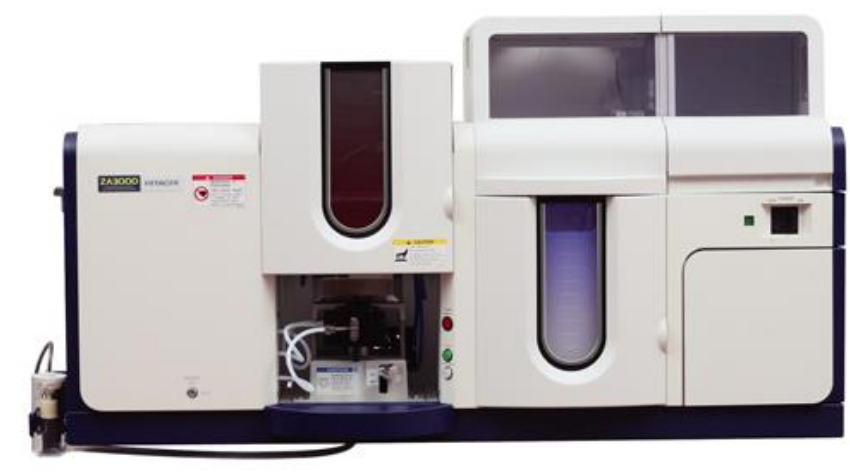

Figure 1. Photo of HITACHI Z-2000

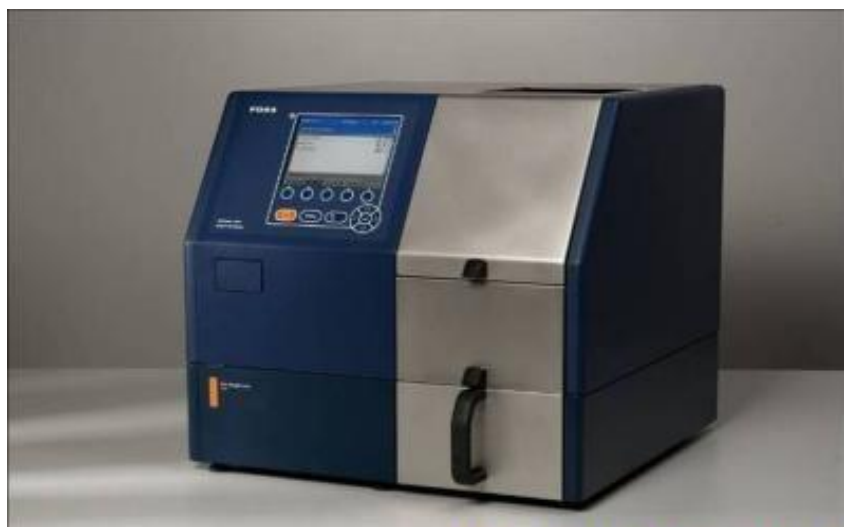

Figure 2. Photo of FOSS

\section{Results and analysis}

\section{Lead accumulation in soil and paddy plant under soil zeolite stress}

Table 2 shows the lead contents of the root, stem, leaf and rice unit masses at treatment I was 1.27, 0.87, 0.96 and 0.91 times that of the CK group respectively. The $\mathrm{Pb}$ content per unit mass of soil increases from treatment III to treatment $\mathrm{V}$, however, no obvious difference was observed. The maximum value of $\mathrm{Pb}$ content in soil at treatment $\mathrm{V}$ was 2.06 times that of treatment $\mathrm{I}(\mathrm{P}<0.05)$. The $\mathrm{Pb}$ content per unit mass of root first rose and then dropped, and difference among various treatment methods was obvious. The maximum value of $\mathrm{Pb}$ content in roots at treatment IV was 2.13 times that of treatment $\mathrm{I}(\mathrm{P}<0.05)$. The values of $\mathrm{Pb}$ content per unit mass of stems, leaves and rice increases, and values of treatment $\mathrm{V}$ were $146 \%, 159 \%$ and $146 \%(\mathrm{P}<0.05)$ that of treatment $\mathrm{I}$, respectively. The $\mathrm{Pb}$ content per unit mass of roots, stems, leaves and rice under treatment II were $1.48,0.84,0.81$ and 0.81 times that of $\mathrm{CK}$ group. The $\mathrm{Pb}$ content per unit mass of soil increased from treatment VI to treatment VIII, but the difference seemed to be non-significant. The maximum value of $\mathrm{Pb}$ content in soil at treatment VIII was 1.83 times that of treatment II $(\mathrm{P}<0.05)$. The $\mathrm{Pb}$ content per unit mass of roots first rose and then dropped, and the difference among various treatment was significant. The maximum value of $\mathrm{Pb}$ content in roots at treatment VII was 1.93 times that of treatment II $(\mathrm{P}<0.05)$. The values of $\mathrm{Pb}$ content per unit mass of stem, leaf and rice increased and the values of treatment VIII were 142\%, 169\% and $139 \%$ 
that of treatment II $(\mathrm{P}<0.05)$. With $0.15 \mathrm{mg} \cdot \mathrm{L}^{-1}$ extraneous lead concentration, the $\mathrm{Pb}$ content per unit mass of roots under $5000 \mathrm{~kg} \cdot \mathrm{ha}^{-1}$ zeolite application is $18.39 \%$ higher than that of $2500 \mathrm{~kg} \cdot \mathrm{ha}^{-1}$ zeolite application, while the $\mathrm{Pb}$ content per unit mass of stem, leaf and rice was lower by $18.10 \%, 24 \%$ and $10.84 \%$ respectively. Treated with $0.20 \mathrm{mg} \cdot \mathrm{L}^{-1}$ extraneous lead concentration, the $\mathrm{Pb}$ content per unit mass of roots increased by $5.01 \%$, while the $\mathrm{Pb}$ content per unit mass of stem, leaf and rice declined by $14.63 \%, 13.27 \%$ and $11.70 \%$ respectively. Treated with $0.25 \mathrm{mg} \cdot \mathrm{L}^{-1}$ extraneous lead concentration, the $\mathrm{Pb}$ content per unit mass of roots rose by $2.38 \%$, while the $\mathrm{Pb}$ content per unit mass of stem, leaf and rice declined by $5.29 \%, 9.77 \%$ and $15.87 \%$, respectively.

Table 2. Effects of exogenous $\mathrm{Pb}$ on Pb contents of rice seedlings under zeolite stress ( $\mathrm{mg}^{\cdot} \mathrm{kg}^{-1}$ )

\begin{tabular}{c|c|c|c|c|c}
\hline Treatment & Soil & Root & Stem & Leaf & Rice \\
\hline CK & $32.89+0.00 \mathrm{c}$ & $20.42+0.00 \mathrm{e}$ & $3.44+0.00 \mathrm{~cd}$ & $2.87+0.00 \mathrm{~b}$ & $0.94+0.00 \mathrm{c}$ \\
I & $32.89+0.00 \mathrm{c}$ & $26.04+0.00 \mathrm{~d}$ & $3.00+0.00 \mathrm{e}$ & $2.76+0.00 \mathrm{~b}$ & $0.86+0.00 \mathrm{~cd}$ \\
II & $33.91+0.00 \mathrm{c}$ & $30.30+0.00 \mathrm{~d}$ & $2.89+0.00 \mathrm{e}$ & $2.35+0.00 \mathrm{bc}$ & $0.76+0.00 \mathrm{~d}$ \\
III & $64.49+3.58 \mathrm{ab}$ & $41.60+6.14 \mathrm{c}$ & $2.21+0.03 \mathrm{f}$ & $2.00+0.57 \mathrm{~cd}$ & $0.83+0.01 \mathrm{~cd}$ \\
IV & $65.47+0.61 \mathrm{ab}$ & $55.71+0.54 \mathrm{a}$ & $3.76+0.14 \mathrm{bc}$ & $2.94+0.63 \mathrm{~b}$ & $0.94+0.00 \mathrm{c}$ \\
V & $67.84+1.94 \mathrm{a}$ & $46.16+1.18 \mathrm{~b}$ & $4.34+0.05 \mathrm{a}$ & $4.40+0.05 \mathrm{a}$ & $1.26+0.15 \mathrm{a}$ \\
VI & $61.05+4.86 \mathrm{~b}$ & $49.25+4.24 \mathrm{~b}$ & $1.81+0.72 \mathrm{f}$ & $1.52+0.05 \mathrm{~d}$ & $0.74+0.01 \mathrm{~d}$ \\
VII & $61.59+4.78 \mathrm{~b}$ & $58.50+0.67 \mathrm{a}$ & $3.21+0.11 \mathrm{de}$ & $2.55+0.03 \mathrm{bc}$ & $0.83+0.01 \mathrm{~cd}$ \\
VIII & $62.11+4.11 \mathrm{~b}$ & $47.26+1.41 \mathrm{~b}$ & $4.11+0.14 \mathrm{ab}$ & $3.97+0.54 \mathrm{a}$ & $1.06+0.13 \mathrm{~b}$ \\
\hline
\end{tabular}

Different lowercase indicates significant differences $(\mathrm{P}<0.05)$ among treatments

\section{Effects of exogenous $\mathrm{Pb}$ on biomass of rice seedlings}

The biomass of rice at maturation period is given in Table 3. Table 3 shows the biomass of root, shoot and whole plant in treatment I was higher than that of the CK group by $45.08 \%, 8.58 \%$ and $11.48 \%$ respectively. The biomass of root, shoot and whole plant in treatment III was $0.71,1.16$ and 1.10 times that of treatment I. According to the coefficients, the biomass of each part of the plants first rose and then dropped with the increase of exogenous $\mathrm{Pb}$ concentration. The biomass of root in treatment IV was $8.65 \%$ less than that of treatment I, while the biomass of shoot and whole plant in treatment IV was more than that of treatment I by $4.22 \%$ and $4.08 \%$, but all values were still higher than CK group. The difference between treatment IV and treatment V was significant. In addition, the height of rice was positively correlated with the dry weight of the whole plant with a correlation coefficient of 0.359 ( $\mathrm{P}<0.05)$.

The biomass of root, shoot and whole plant in treatment II was higher than that of the CK group by $63.04 \%, 2.47 \%$ and $14.01 \%$ respectively. The biomass of root, shoot and whole plant in treatment VI was $0.93,1.27$ and 1.17 times that of treatment II. According to the coefficients, the biomass of each parts of the plant first rose and then dropped with the increase of exogenous $\mathrm{Pb}$ concentration. The biomass of root and whole plant in treatment VII was less than that of treatment II by $34.85 \%$ and $5.34 \%$ respectively, while the biomass of shoot in under treatment VII was $5.59 \%$ more than that of treatment II, but the values were still higher than that of the CK group. There was an obvious difference between treatment VII and VIII. There was positive correlation between the tiller number and dry weight of whole plant with the correlation coefficient at $0.491(\mathrm{P}<0.05)$. At an extraneous lead concentration of $0.15 \mathrm{~kg} \cdot \mathrm{L}^{-1}$, the 
dry weight of whole plant applied by $5000 \mathrm{~kg} \cdot \mathrm{ha}^{-1}$ zeolite was higher than that of $2500 \mathrm{~kg} \cdot \mathrm{ha}^{-1}$ zeolite by $9.07 \%, 0.20 \mathrm{mg} \cdot \mathrm{L}^{-1}$ by $1.83 \%, 0.25 \mathrm{mg} \cdot \mathrm{L}^{-1}$ by $1.92 \%$.

Table 3. Effects of the exogenous $\mathrm{Pb}$ on the growth of rice under zeolite stress

\begin{tabular}{c|c|c|c|c|c|c}
\hline \multirow{2}{*}{ Treatment } & \multicolumn{3}{|c|}{ Biomass (dry weight)/g·treatment $\mathbf{~}^{\mathbf{1}}$} & \multirow{2}{*}{ Plant height/cm } & Tiller number & \multirow{2}{*}{ Coefficient } \\
\cline { 2 - 6 } & Root & Shoot & Whole plant & & & \\
\hline CK & $24.69 \pm 5.06 \mathrm{~cd}$ & $141.24 \pm 16.72 \mathrm{c}$ & $165.93 \pm 16.36 \mathrm{c}$ & $101.00 \pm 2.65 \mathrm{ab}$ & $15.33 \pm 4.51 \mathrm{ab}$ & - \\
I & $35.82 \pm 13.73 \mathrm{abc}$ & $153.36 \pm 7.69 \mathrm{abc}$ & $184.98 \pm 3.57 \mathrm{abc}$ & $93.33 \pm 4.16 \mathrm{c}$ & $11.00 \pm 0.00 \mathrm{~b}$ & 1.11 \\
II & $40.25 \pm 7.65 \mathrm{~d}$ & $144.73 \pm 6.56 \mathrm{bc}$ & $189.18 \pm 16.68 \mathrm{abc}$ & $101.00 \pm 3.00 \mathrm{ab}$ & $18.67 \pm 5.77 \mathrm{a}$ & 1.14 \\
III & $25.30 \pm 0.71 \mathrm{bcd}$ & $177.41 \pm 6.69 \mathrm{ab}$ & $202.7 \pm 6.03 \mathrm{abc}$ & $105.000 \pm 1.73 \mathrm{a}$ & $11.00 \pm 3.61 \mathrm{~b}$ & 1.22 \\
IV & $32.72 \pm 2.54 \mathrm{abc}$ & $159.84 \pm 10.27 \mathrm{abc}$ & $192.53 \pm 8.19 \mathrm{abc}$ & $105.00 \pm 4.36 \mathrm{a}$ & $14.00 \pm 1.73 \mathrm{ab}$ & 1.16 \\
V & $29.04 \pm 8.43 \mathrm{~d}$ & $151.89 \pm 9.37 \mathrm{~d}$ & $180.93 \pm 16.50 \mathrm{e}$ & $93.33 \pm 1.53 \mathrm{c}$ & $12.00 \pm 0.00 \mathrm{~b}$ & 1.09 \\
VI & $37.63 \pm 4.97 \mathrm{~cd}$ & $183.45 \pm 8.50 \mathrm{a}$ & $221.08 \pm 13.21 \mathrm{a}$ & $102.33 \pm 3.79 \mathrm{a}$ & $13.00 \pm 1.00 \mathrm{ab}$ & 1.33 \\
VII & $36.22 \pm 5.26 \mathrm{~d}$ & $159.82 \pm 7.67 \mathrm{abc}$ & $196.05 \pm 11.25 \mathrm{bc}$ & $104.33 \pm 3.79 \mathrm{a}$ & $14.00 \pm 2.00 \mathrm{ab}$ & 1.18 \\
VIII & $29.13 \pm 8.03 \mathrm{abcd}$ & $155.27 \pm 9.93 \mathrm{~d}$ & $184.40 \pm 4.87 \mathrm{~d}$ & $96.67 \pm 2.31 \mathrm{bc}$ & $13.67 \pm 0.58 \mathrm{ab}$ & 1.11 \\
\hline
\end{tabular}

The coefficient $=$ total biological yield in all treatments/total biological yield in CK group

Zeolite was applied to paddy soil irrigated with lead wastewater. The effects of different zeolite application rates on rice yield are shown in Table 4. Table 4 shows when the application amount of zeolite was $2500 \mathrm{~kg} \cdot \mathrm{ha}^{-1}$, the $0 \mathrm{~kg} \cdot \mathrm{ha}^{-1}$ group without zeolite was used as the control group. The irrigation with different concentrations of lead water increased the yield of clean water by $5.9 \%$, while the other treatments decreased by $3.77 \%, 8.7 \%$ and $17.6 \%$, respectively. When the amount of zeolite was $5000 \mathrm{~kg} \cdot \mathrm{ha}^{-1}$, the rice yield showed an upward trend compared with that of $0 \mathrm{~kg} \cdot \mathrm{ha}^{-1}$. The rice yield was $8.84 \%, 11.20 \%, 16.84 \%$ and $8.50 \%$ higher than that of the control group under different concentrations of lead-containing water irrigation, and the difference reached a significant level $(\mathrm{p}<0.05)$.

Table 4. Effects of different lead concentrations of irrigation water and different amount of zeolite application on rice yield $\left(g \cdot\right.$ area $\left.^{-1}\right)$

\begin{tabular}{c|c|c|c}
\hline \multirow{2}{*}{$\begin{array}{c}\text { Concentration of } \\
\text { irrigation water/mg } \cdot \mathbf{L}^{-\mathbf{1}}\end{array}$} & $\mathbf{0}$ & $\mathbf{2 5 0 0}$ & $\mathbf{A p p l i c a t i o n ~ a m o u n t ~ o f ~ z e o l i t e / \mathbf { k g } \cdot \mathbf { h a } \mathbf { - 1 }}$ \\
\cline { 2 - 4 } & $2058.84+105.09 \mathrm{ab}$ & $2180.88+50.64 \mathrm{a}$ & $2240.88+50.64 \mathrm{~d}$ \\
0.25 & $2010.48+121.08 \mathrm{ab}$ & $1655.08+44.62 \mathrm{a}$ & $2235.56+50.99 \mathrm{~b}$ \\
0.2 & $2396.04+339.83 \mathrm{a}$ & $2187.84+24.9 \mathrm{a}$ & $2799.68+59.51 \mathrm{a}$ \\
0.15 & $2273.48+12.143 \mathrm{~b}$ & $2113.16+53.15 \mathrm{~b}$ & $2467.92+48.52 \mathrm{c}$ \\
\hline
\end{tabular}

The coefficient $=$ total biological yield in all treatments/total biological yield in CK group

When the concentration of lead water was 0.15 , the production of $0 \mathrm{~kg} \cdot \mathrm{ha}^{-1}$ increased by $10.43 \%$, that of $2500 \mathrm{~kg} \cdot \mathrm{ha}^{-1}$ increased by $0.1 \%$, and that of $5000 \mathrm{~kg} \cdot \mathrm{ha}^{-1}$ increased by $10.13 \%$ with the addition of different zeolite. When the lead concentration was $0.2 \mathrm{mg} \cdot \mathrm{L}^{-1}$, the $0 \mathrm{~kg} \cdot \mathrm{ha}^{-1}$ yield increased by $16.38 \%$ with different zeolite addition. The yield of $5000 \mathrm{~kg} \cdot \mathrm{ha}^{-1}$ increased by $24.94 \%$ and $14.08 \%$ respectively. When the concentration of lead water is $0.25 \mathrm{mg} \cdot \mathrm{L}^{-1}$, the $0 \mathrm{~kg} \cdot \mathrm{ha}^{-1}$ yield decreases by $2.35 \%$ with different zeolite addition. The yield of $5000 \mathrm{~kg} \cdot \mathrm{ha}^{-1}$ decreased by $0.24 \%$ and $24.11 \%$ respectively. 
The results showed that when the amount of zeolite in soil was $2500 \mathrm{~kg} \cdot \mathrm{ha}^{-1}$, it had an inhibitory effect on rice yield, while when the amount of zeolite was increased to $5000 \mathrm{~kg} \cdot \mathrm{ha}^{-1}$, it had an promoting effect on rice yield, and in irrigation water with different lead concentrations, the effect of zeolite on rice yield was different, and it played an promoting role in $\mathrm{CK}$.

\section{Effects of different treatment on nutritional quality of rice}

The water content in rice irrigated by lead water fluctuated under soil zeolite stress. Table 5 shows the water contents of rice at treatment I were higher than that of the CK group. The water contents of rice from treatment III to treatment V were obviously higher than that of treatment $\mathrm{I}$, which indicated that the effect of exogenous $\mathrm{Pb}$ on water content were not significant under soil zeolite stress. In this experiment, the protein content in rice irrigated by lead water fluctuated under soil zeolite stress. When irrigated with water of the same lead concentration, the protein content of rice treated with treatment VI-VIII was lower than that of treatment III-V, but higher than the CK group irrigated by clean water. It indicated that exogenous $\mathrm{Pb}$ under soil zeolite stress had negative effects on the protein content in rice at different extents. The amylase content in rice fluctuated in a non-significant range. The rice under treatment VIII had the lowest amylon content at $15.6 \%$, which was lower than the CK group by $6.02 \%$. Therefore, the effect seemed significant $(\mathrm{P}<0.05)$. The water and amylase contents of rice in different treatment satisfied the green rice standard (water content $\leq 15.5 \%$, amylase content $=13.0 \% \sim 20.0 \%$ ).

Table 6 shows the regression equation is based on effect of interaction of zeolite and lead on protein content in rice. It is shown that the effect of interaction of zeolite and lead on protein content in rice is significant, especially the effect of $A^{2} B$ and $A B^{2}$ on the results is quite influential based on the $F$ values, which represents the concentration of zeolite and lead. The effect of lead concentration on protein content is stronger than zeolite amount.

The taste of rice mainly depends on amylase, protein water contents as well as fatty acid value. The taste is in inversely proportional to the amylase and protein contents but proportional to water content. Calculated using software Design-Expert 8.0, the optimum combination is as follows: zeolite $5000 \mathrm{~kg} \cdot \mathrm{ha}^{-1}$, lead concentration in water $0.19 \mathrm{mg} \cdot \mathrm{L}^{-1}$. Under such optimum condition, the predicted protein content is $6.96 \%$, water content is $11.07 \%$ and amylase content is $16.29 \%$, which all meet the green rice standard.

Table 5. The notability analysis after different treatments

\begin{tabular}{c|c|c|c}
\hline Treatment & Water content & Protein content & Amylase content \\
\hline CK & $10.43 \mathrm{~b}$ & $7.33 \mathrm{~b}$ & $16.56 \mathrm{~b}$ \\
I & $10.47 \mathrm{~b}$ & $8.23 \mathrm{a}$ & $16.67 \mathrm{~b}$ \\
II & $11.07 \mathrm{a}$ & $7.33 \mathrm{~b}$ & $16.63 \mathrm{~b}$ \\
III & $11.07 \mathrm{ab}$ & $6.97 \mathrm{bc}$ & $16.73 \mathrm{~b}$ \\
IV & $10.26 \mathrm{~b}$ & $6.23 \mathrm{~d}$ & $16.4 \mathrm{~b}$ \\
V & $10.6 \mathrm{~b}$ & $7.1 \mathrm{bc}$ & $15.9 \mathrm{a}$ \\
VI & $11.07 \mathrm{a}$ & $7.2 \mathrm{bc}$ & $16.57 \mathrm{~b}$ \\
VII & $11.07 \mathrm{ab}$ & $6.77 \mathrm{c}$ & $16.67 \mathrm{~b}$ \\
VIII & $10.8 \mathrm{ab}$ & $6.1 \mathrm{bc}$ & $15.6 \mathrm{a}$ \\
\hline
\end{tabular}


Table 6. Significance test with coefficient of regression equation

\begin{tabular}{c|c|c|c|c|c}
\hline Source & Quadratic sum & Degree of freedom & Mean square & F value & P value \\
\hline Model & 6.64 & 8.00 & 0.83 & 19.48 & 0.0165 \\
A-zeolite & 0.00 & 1.00 & 0.00 & 0.06 & 0.8224 \\
B-lead concentration & 0.01 & 1.00 & 0.01 & 0.24 & 0.6549 \\
AB & 0.73 & 1.00 & 0.73 & 17.06 & 0.0258 \\
$\mathrm{~A}^{2}$ & 0.00 & 1.00 & 0.00 & 0.02 & 0.9060 \\
$\mathrm{~B}^{2}$ & 0.02 & 1.00 & 0.02 & 0.47 & 0.5435 \\
$\mathrm{~A}^{2} \mathrm{~B}$ & 1.15 & 1.00 & 1.15 & 27.05 & 0.0138 \\
$\mathrm{AB}^{2}$ & 0.89 & 1.00 & 0.89 & 20.90 & 0.0196 \\
$\mathrm{~A}^{3}$ & 0.00 & 0.00 & & & \\
$\mathrm{~B}^{3}$ & 0.06 & 1.00 & 0.06 & 1.48 & 0.3101 \\
\hline
\end{tabular}

\section{Discussion}

Over the recent years, several heavy metal pollution accidents have occurred, threatening lives and health. Much research on heavy metal pollution has been carried out, with some progress achieved. It has been discovered that biochar itself has a high $\mathrm{pH}$ value, thus the addition of $5 \%$ biochar in soil can enhance its $\mathrm{pH}$ value. With the addition of biochar, the effectiveness of $\mathrm{Pb}$ and $\mathrm{Cd}$ can be reduced, and the state conversion of $\mathrm{Pb}$ and $\mathrm{Cd}$ can thus be stabilized. The addition of biochar can also improve the physical and chemical properties of soil affected by combined pollution. Moreover, it can effectively adsorb heavy metal ions, therefore promoting the adsorption of $\mathrm{Pb}$ and $\mathrm{Cd}$ in soil and reducing the biological effectiveness of $\mathrm{Pb}$ and $\mathrm{Cd}$ (Gao et al., 2016). Under certain conditions, heavy metals in the adsorption and precipitation states were able to be exchanged between soil solutions, thus reducing the $\mathrm{pH}$ value and promoting the release of heavy metals in the adsorption state into the soil. In such cases, the absorption of heavy metals by plants will increase. In the current study, the application of zeolite in paddy plant soil irrigated with water of different lead concentrations was demonstrated to inhibit the migration of $\mathrm{Pb}$ to paddy plants, thus improving the quality of paddy plants. The effect of the zeolite application in soil on $\mathrm{pH}$ values is worth further research.

Several studies have reported that zeolite mixed with urea increased rice grain yields in flooded paddy fields (Kavoosi, 2007; Gevrek et al., 2009; Sepaskhah and Barzegar, 2010), the results are consistent with the experimental results. However, Research on the effect of lead on the growth of toona ciliata indicated that the total biomass of the whole toona ciliata plant decreases significantly with the increase of the $\mathrm{Pb}$ stress gradient, while the biomass of the plant organs (withered leaves, leafstalk) increased with the increase of the $\mathrm{Pb}$ stress gradient. This differs from the results of the effects on paddy rice biomass in this study. The soil condition was also an important factor found to affect the growth of toona ciliata and $\mathrm{Pb}$ absorption and accumulation. With the same $\mathrm{Pb}$ stress gradient, alkaline purple calcium soil had an impact on the $\mathrm{Pb}$ effectiveness, and was able to reduce the toxic effect of $\mathrm{Pb}$ on toona ciliate (Hu et al., 2012). The study demonstrated that when exogenous $\mathrm{Pb}$ entered the soil, the original forms of $\mathrm{Pb}$ in the soil clearly changed, revealing that exogenous $\mathrm{Pb}$ is maintained in a dynamic conversion process. The application of soil conditioner reduced the content of $\mathrm{Pb}$ in an effective state and inhibited the migration of $\mathrm{Pb}$ in the soil-plant system. It benefited safe production of plants (Chen et al., 2008). The study of Zhao et al. (2012) suggested that a single treatment with low concentrations of $\mathrm{Cd}$ and $\mathrm{Pb}$ can promote the growth of 
pilea cadierei, but inhibit its growth when the concentration exceeds a certain level. Under a combined treatment with various concentrations, the inhibiting effect on the growth of pilea cadierei was strengthened with the increase of metal concentrations. The $\mathrm{Cd}$ and $\mathrm{Pb}$ absorbing capacities of the leaf, stalk and root of pilea cadierei demonstrated strong significant positive correlations, with the accumulation in the root being the most influential. Under a combined treatment, the heavy metal accumulation in each part of the plant rose. Total migration of $\mathrm{Cd}$ and $\mathrm{Pb}$ in the above ground part of pilea cadierei was large. In particular, under $\mathrm{Cd}-\mathrm{Pb}$ combined treatment, the total migration of $\mathrm{Pb}$ in the above ground part was much more than that under a single treatment with the same concentration of $\mathrm{Pb}$. Therefore when the soil is polluted by heavy metals, ornamental plants can be planted to absorb the heavy metal, thus promoting ecological restoration.

\section{Conclusions}

(1) Table 2 shows that most of the lead remains in soil and rice roots, and only a small amount migrates to aboveground plants. The unit content of lead in each part of the paddy plant was affected on different levels. The application of zeolite can reduce above ground plant absorption of $\mathrm{Pb}$, inhibit the migration of $\mathrm{Pb}$ into rice and optimize the quality of rice. The effect of zeolite application in soil on $\mathrm{pH}$ value is worth further studying.

(2) Tables 3 and 4 show that shows that for lead water irrigation under soil zeolite stress, the paddy rice plant height, and the above, below ground dry weight and yield all increased significantly. The effect of zeolite was influenced by $\mathrm{Pb}$ concentration in the irrigation water. Higher $\mathrm{Pb}$ concentrations resulted in a higher inhibition effect.

(3) Table 5 shows that the water content in rice increased and the protein content decreased with the increase of zeolite addition. Thus, the application of zeolite has a negative effect on protein content. The starch content decreased with the increase of zeolite addition. Under different treatments, both water content and amylose content in the rice satisfy the green rice standard (water content $\leq 15.5 \%$; amylose content 13.0$20.0 \%)$.

\section{REFERENCES}

[1] Abrahams, P. W. (2002): Soils: their implications to human health. - Science of the Total Environment 29(1/2/3): 1-32.

[2] Aghaalikhani, M., Gholamhoseini, M., Dolatabadian, A., Khodaei-Joghan, A., Sadat Asilan, K. (2012): Zeolite influences on nitrate leaching, nitrogen-use efficiency, yield and yield components of canola in sandy soil. - Arch. Archives of Agronomy and Soil Science 58: 1149-1169.

[3] Altaf, H. L., Zhang, Z., Sabry, M., Shaheen, J. R., Guo, Z., Li, R., Amanullah, M., Wang, Z., Ren, C., Mi, S., Liu, T., Jing, R. (2019): Mono-and co-applications of Ca-bentonite with zeolite, Ca-hydroxide, and tobacco biochar affect phytoavailability and uptake of copper and lead in a gold mine-polluted soil. - Journal of Hazardous Materials 374.

[4] Ashraf, U., Kanu, A. S., Mo, Z. W., Hussain, S., Anjum, S. A., Khan, I., Abbas, R. N., Tang, X. (2015): Lead toxicity in rice; effects, mechanisms and mitigation strategies-a mini review. - Environmental Science and Pollution Research 22: 18318-18332.

[5] Becerra, C., Lopes, A., Vaz, I., Silva, E., Manaia, C., Nunes, O. (2015): Wastewater reuse in irrigation: a microbiological perspective on implications in soil fertility and human and environmental health. - Environment International 75: 117-135. 
[6] Chen, D., Zhou, Y., Zhang, J., et al. (2018): Human health risk assessment owing to Pb and $\mathrm{Zn}$ of farmland soils in Shifang City, Southwest China. - Journal of AgroEnvironment Science 37(12): 2687-2693.

[7] Chen, H., Zheng, W., Tang, W. (2008): The effectiveness of amendment on $\mathrm{Pb}$ form and bioavailability in Pb contaminated soil. - Journal of Agro. Environment Science 27(1): 0170-0173.

[8] Chen, X., Niu, J., Cui, Y. (2010): Bioaccessibility of lead in urban topsoil and its health risk assessment: a case study of a small area near Shougang group. - Environmental Science 3(12): 3028-3035.

[9] Galvis, A., Jaramillo, M. F., van der Steen, P., Gijzen, H. J. (2018): Financial aspects of reclaimed wastewater irrigation in three sugarcane production areas in the Upper Cauca river Basin, Colombia. - Agricultural Water Management 209: 102-110.

[10] Gao, R., Zhu, J., Tang, F., Hu, H., Fu, Q., Wan, T. (2016): Fractions transformation of $\mathrm{Cd}, \mathrm{Pb}$ in contaminated soil after short-term application of rice straw biochar. - Acta Scientiae Circumstantiae 01: 251-256.

[11] Gevrek, M. N., Tatar, Ö., Yagmur, B., Özaydin, S. (2009): The effects of clinoptilolite application on growth and nutrient ions content in rice grain. - Turkish Journal of Field Crops 14: 79-88.

[12] Gray, C. W., Dunham, S. J., Dennis, P. G., et al. (2006): Field evaluation of in situ remediation of a heavy metal contaminated soil using lime and red-mud. - Environmental Pollution 142(3): 530-539.

[13] Hazrati, S., Tahmasebi-Sarvestani, Z., Mokhtassi-Bidgoli, A., Modarres-Sanavy, S. A. M., Mohammadi, H., Nicola, S. (2017): Effects of zeolite and water stress on growth, yield and chemical compositions of Aloe vera L. - Agric-Water Manage 181: 66-72.

[14] Hu, F., Zhang, J., Yang, W., Wu, F., Liu, Y., Liu, Yan, B., Huang, X. (2012): Effects of $\mathrm{Pb}$ stress on the growth, development and $\mathrm{Pb}$ enrichment properties of Toona ciliata Roem saplings. - Journal of Agro-Environment Science 02: 284-291.

[15] Huang, J., Hsu, S., Wang, S. (2011): Effects of rice straw ash amendment on $\mathrm{Cu}$ solubility and distribution in flooded rice paddy soil. - Journal of Hazardous Materials 186: 1801-1807.

[16] Kavoosi, M. (2007): Effects of zeolite application on rice yield, nitrogen recovery, and nitrogen use efficiency. - Communications in Soil Science and Plant Analysis 38: 69-76.

[17] Khush, G. S. (2013): Strategies for increasing the yield potential of cereals: case of rice as an example. - Plant Breed 132: 433-436.

[18] Luo, X., Yu, S., Li, X. (2012): The mobility, bioavailability and human bioaccessibility of trace metals in urban soils of Hong Kong. - Applied Geochemistry 27(5): 995-1004.

[19] Malekian, R., Abedi-Koupai, J., Eslamian, S. (2011): Influences of clinoptilolite and surfactant-modified clinoptilolite zeolite on nitrate leaching and plant growth. - Journal of Hazardous Materials 185: 970-976.

[20] Merrikhpour, H., Jalali, M. (2013): Comparative and competitive adsorption of cadmium, copper, nickel, and lead ions by Iranian natural zeolite. - Clean Technologies and Environmental Policy 15(2): 303-316.

[21] Qian, G., Chen, W., Lim, T., et al. (2009): In-situ stabilization of Pb, Zn, Cu, Cd and Ni in the multi-contaminated sediments with ferrihyrite and apatite composite additives. Journal of Hazardous Materials 170(2/3): 1093-1100.

[22] Sepaskhah, A. R., Barzegar, M. (2010): Yield, water and nitrogen-use response of rice to zeolite and nitrogen fertilization in a semi-arid environment. - Agricultural Water Management 98: 38-44.

[23] Shi, W., Shao, H., Li, H., Shao, M., Du, S., et al. (2009): Progress in the remediation of hazardous heavy metal-polluted soils by natural zeolite. - Journal of Hazardous Materials 170(1): 1-6. 
[24] Theodoratos, P., Papassiopi, N., Xenidis, A. (2002): Evaluation of monobasic culcium phosphate for the immobilization of heavy metals in contaminated soils from Lavrion. Journal of Hazardous Materials 94(2): 135-146.

[25] Wu, Y., Zhou, H., Yang, W., Zou, Z., Zhu, W., Gu, J., Peng, P., Zhang, P., Zeng, M., Liao, B. (2016): Comparison of the persistence of a combined amendment stabilizing $\mathrm{Pb}$, $\mathrm{Cd}, \mathrm{Cu}$ and $\mathrm{Zn}$ in polluted paddy soil. - Environmental Science 37(7).

[26] Yang, W., Zhou, H., Deng, G., et al. (2016): Effects of combined amendment on bioavailability of $\mathrm{Pb}, \mathrm{Cd}$, and As in polluted paddy soil. - Acta Scientiae Circumstantiae 36(1): 257-263.

[27] Zhang, L., Mo, Z., Qin, J., et al. (2014): Contamination of heavy metals in soils and health risk assessment in children in a downstream village of Dachang mining area in Guangxi. - Journal of Environmental and Health 31(6): 512-516.

[28] Zhao, F., Ma, Y., Zhu, Y., Tang, Z., McGrath, S. P. (2015): Soil contamination in China: current status and mitigation strategies. - Environmental Science \& Technology 49: 750759.

[29] Zhao, Y., Pan, Y., Liu, B., Yang, H., Hou, Y., Zhang, J., Cai, L. (2012): Pilea cadierei Gagnep. et Guill's growth and accumulation under single and combined pollution of $\mathrm{Cd}$ and $\mathrm{Pb}$. - Journal of Agro-Environment Science 31(1): 48-53.

[30] Zhou, H., Zhou, X., Zeng, M., Liao, B., Liu, B., Yang, W., Wu, Y., Qiu, Q., Wang, Y. (2014a): Effects of combined amendments on heavy metal accumulation in rice (Oryza sativa L.) planted on contaminated paddy soil. - Ecotoxicology and Environmental Safety 101: 226-232.

[31] Zhou, H., Zhou, X., Zeng, M., Liu, L., Yang, W., Wang, Y., Liao, B. (2014b): Effects of two combined amendments on heavy metal bioaccumulation in paddy soil. - China Environmental Science 34(2): 437444.

[32] Zhou, R., Liu, X., Luo, L., Zhou, Y., Wei, J., Chen, A., Tang, L., Wu, H., Deng, Y., Zhang, F., Wang, Y. (2017): Remediation of $\mathrm{Cu}, \mathrm{Pb}, \mathrm{Zn}$ and Cd-contaminated agricultural soil using a combined red mud and compost amendment. - International Biodeterioration \& Biodegradation 118: 73-81. 